Susan Gingell and Wendy Roy, eds., Listening up, Writing Down and Looking Beyond: Opening the Door to Transdisciplinary, Multimodal Communication

\title{
Christophe Lebold
}

\section{(2) OpenEdition}

\section{Journals}

Electronic version

URL: https://journals.openedition.org/ces/5703

DOI: $10.4000 /$ ces. 5703

ISSN: 2534-6695

\section{Publisher}

SEPC (Société d'études des pays du Commonwealth)

\section{Printed version}

Date of publication: 1 April 2015

Number of pages: 113-115

ISSN: 2270-0633

\section{Electronic reference}

Christophe Lebold, "Susan Gingell and Wendy Roy, eds., Listening up, Writing Down and Looking Beyond: Opening the Door to Transdisciplinary, Multimodal Communication", Commonwealth Essays and Studies [Online], 37.2 | 2015, Online since 13 April 2021, connection on 17 July 2021. URL: http:// journals.openedition.org/ces/5703 ; DOI: https://doi.org/10.4000/ces.5703

This text was automatically generated on 17 July 2021.

\section{$(1) \Theta \Theta$}

Commonwealth Essays and Studies is licensed under a Licence Creative Commons Attribution - Pas d'Utilisation Commerciale - Pas de Modification 4.0 International. 


\title{
Susan Gingell and Wendy Roy, eds., Listening up, Writing Down and Looking Beyond: Opening the Door to Transdisciplinary, Multimodal Communication
}

\author{
Christophe Lebold
}

\section{REFERENCES}

Susan Gingell and Wendy Roy, eds. Listening up, Writing Down and Looking Beyond: Opening the Door to Transdisciplinary, Multimodal Communication. Waterloo, ON: Wilfrid Laurier UP, 2012. 380 p. ISBN hb: 978-1-55458-364-5. C\$63.75

1 Accompanied by a multi-media webpage with recordings and video stills of several of the performances studied in the book, Listening Up, Writing Down and Looking Beyond is the outcome of a 2008 conference held at the University of Saskatchewan, in connection with a Canadian Council sponsored artistic event, The eVOCative festival of oral performance. It is also the outcome of the editors' decades of engagement with performances of all kinds, mostly in postcolonial and expressive cultures contexts.

In a stimulating and enthusiastic introduction, Gingell and Roy recall their purpose: to pursue, in the face of emerging new "audiocentric genres" of performance (22) - sound poetry, dub and slam among others - the pedagogical enterprise initiated by Richard Foley; to teach audiences "how to read oral poems" in ways which account for their multilayered (i.e., aesthetic, phenomenological and political) dimension. As opposed to pioneering works by Foley, Ong and McLuhan (acknowledged here as important sources), Gingell and Roy shift the focus from strict opposition between the written and the oral to their interactions and interdependency, and the overlapping of the strictly 
oral/aural with the visual, the written and the social. Hence Gingell and Roy's introduction of the term of "oral +" to emphasize the idea that orality is always more than orality; for instance it also implies bodies and specific social contexts.

This vision is perceptible in the outline of the book, the seventeen contributions being grouped into three sections: "performance poetics," "print textualizations of the oral +," and "the oral/visual interface" - a threefold structure which seems to promise a complex investigation of performance by examining what it inherently is, what it loses on the page, and its interactions with the visual field. A major concern in the book is to keep the overall enterprise as pedagogical as possible, something that is evident when Gingell and Roy include not only a glossary of key terms in performance studies, but also an in-depth historical and bibliographical survey of theories of orality, from Heidegger's critique of "ocular-centrism" to contemporary "sound history," via Ong and Ruth Finnegan's pioneering studies of oral traditions. All this makes the book a valuable source for anyone interested in studies of orality.

4 The editors' central belief is that performance is first and foremost a holistic experience that is both synesthetic and political: a joyful stimulation of the senses of the audience and of their social imagination. They constantly stress that performance is power because sound and movement is energy, and "orature" is nothing if not a transformative and empowering experience that stimulates the agency of all participants. Also central to the volume is the emphasis laid on the politics of performance. When Gingell and Roy define performance not only as an "embodied event" that includes "heightened body and verbal language," but also as a "forum in which histories and social identities are negotiated," (4) they set the tone for a volume largely informed by postcolonial theory, material culture and (more marginally) gender studies.

5 The individual articles cover many sub-genres of orality, from sound poetry to Irish ballads, early modern religious sermons or dub poetry. They also include an analysis of simulated oral voices in contemporary Canadian metafiction, and several texts about transcriptions of oral narratives and indigenous poetry of Yukon, Anishinaabe, Dakota and South African origin. The methodological approaches range from the purely aesthetic - with sound poet Paul Dutton's definition of his art as "spiritual pursuit" (134) - to the sociological - with Helen Gregory's transatlantic study of slam poetry contests. Some articles deal with militant versions of postcolonial studies (with professor and Dakota activist Waziyatawin's exploration of the issue of truth-telling as an active agent of decolonization, in an article that is also a call to arms). Others assert scientificity first and foremost: didactic sciences are present in Hugh Hodges's analysis of his experience of "teaching" Performance Poetry in a 2008 undergraduate class, and so is linguistics, in Mareike Neuhaus's approach to texts by Cree poet Louise Bernice Halfe from the perspective of the inner structures of the Cree language (with a particular view to the "holophrases" - or word bundles - typical of polysynthetic languages).

6 The reader is in for many moments of insight or conceptual breakthrough. For instance with Paul Dutton's idea of a "speech-music continuum," his definition of sound poetry as "an egalitarian art" and his stimulating typology of the various forms of the genre. Or with Gugu Hlongwane's presentation of South-African dub-poet Lesoto Rampolokeng as a "gadfly" poet (148) who writes against the dominant ANR-sanctioned discourse of reconciliation. Or again with Susan Gingell's use of the concept of "sound 
identity" when analyzing Cree poet Neal McLeod's attempt to "traditionalize modernity" (and postmodernity) by inserting Cree language (and the Cree worldview) into the world of the Internet or multichannel TV. A key moment in the collection is George Elliott Clark's examination of how, in the face of both white critical pressure on the black text and of a specifically black anxiety of performance due to the sociocultural necessity of embodying a resistant voice and adopting a "preaching function" (58), Canadian dub poets d'bi.young and Oni Joseph textualize black voices on the page, using "guerrilla tactics" - that is visual rhetoric and a mixture of literary English and hip-hop rhetoric (61). Clark shows how both poets noisily disrupt the conventions of the silent "white" page, showing in the process that "the orality of Negro poetry will always out, bursting though all stifling blandishments and attempted erasures" (71). Several contributions deal with the ethics of textual editions of oral narratives. Emily Blacker thus uses the concept of "ethics of encounter" to analyze Life Lived Like a Story, a collection of oral testimonies by three Yukon elders edited by ethnographer Julie Cruikshank. Blacker concludes that concessions to the literary market and "generic incompatibilities" between what a "life story" is in aboriginal cultures and what the ethnographer expects has altered the nature and feel of the original interviews and produced a text meant to "facilitate smooth cross-cultural encounters" (255). All highpoints of the book cannot be cited here but each is sufficient to make it worthwhile.

7 For all its merits, Listening up, Writing Down and Looking Beyond also has minor shortcomings.

8 The third section - supposedly dedicated to interactions between performed orality and visual art - fails to keep its promise: only two of the articles really engage with the visual/oral dialectics and it seems that the editors have merely grouped together the contributions that mentioned visuals. A reader interested in systematically exploring interactions between the visual and the oral is bound to be disappointed. Style can be tedious, as some contributions fall into the stylistic traps of academia (theoretical name-dropping, analytical overkill and heavy prose), but, to be fair, a great - and commendable - thrust behind the book is Gingell and Roy's desire to "open up the conversational circle" and expand the definition of what can be called "expert work" (15). Many of the contributors are therefore artists and performers - some with academic positions - and at times political activists. This makes for a welcome sense of urgency in many of the contributions but in some cases, the dominant mode is not so much academic demonstration as militant celebration. The reluctant reader may find limits to some ideological positions: there is at times a slightly demagogical temptation to romanticize "orality" and "folk" as inherent loci of resistance, and it is a relief to the reader when Naomi Foyle reminds us in her analysis of successive reactionary rewritings of an Irish ballad that we should be wary of equating orality with resistance. Several articles are encumbered by political politeness. The opposition Blacker sees between the authenticity of resistant and dignified Yukon women and white anthropologists constrained by "western concepts" and with an eye on the literary market may make the sensitive reader cringe. So does the temptation, perceptible here and there in the volume, to identify a "fantasied enemy" on the white page of the supposedly hegemonical printed text, which stabilizes meaning and constructs an experience that is not multilayered or synesthetic; this is what Gingell calls "the onedimensional text experience" (305). Those of us who still love Rimbaud may feel inclined at times to remind Gingell and Roy that creativity, authenticity and 
rebelliousness are not prerogatives of contemporary militant performers and that some printed texts have been known to generate multilayered (and politically stimulating) experiences too.

\section{AUTHORS}

\section{CHRISTOPHE LEBOLD}

Christophe LEBOLD has published numerous articles on artists like Bob Dylan, Alan Ginsberg and Leonard Cohen after a PhD devoted to rock songs as oral literary objects. He is the author of Leonard Cohen. L'Homme qui voyait tomber les anges (Camion blanc, 2013), a conceptual monograph on the life and work of the Canadian singer-songwriter whom he sees as a modern metaphysical poet. He teaches American literature and performance studies at the University of Strasbourg and is also an actor and stage director. 